\title{
Factors Associated with Echocardiographic Abnormalities in Patients with Chronic Kidney Disease in a Tertiary Hospital in Ivory Coast
}

\author{
Weu M. Tia ${ }^{1}$, Abdoulaye Togo ${ }^{2}$, Manzan A. Wognin'1, Reine M. Koffi ${ }^{1}$, Jonathan Kpan', \\ Bourhaima Ouattara1, Dame A. Gnionsahe ${ }^{2}$ \\ ${ }^{1}$ Department of Internal Medicine, University Teaching Hospital (CHU) of Bouaké, Bouaké, Côte d'Ivoire \\ ${ }^{2}$ Nephrology-Hemodialysis Department, University Teaching Hospital (CHU) of Yopougon, Abidjan, Côte d'Ivoire \\ Email: ${ }^{*}$ Weutia2015@gmail.com
}

How to cite this paper: Tia, W.M., Togo, A., Wognin, M.A., Koffi, R.M., Kpan, J., Ouattara, B. and Gnionsahe, D.A. (2022) Factors Associated with Echocardiographic Abnormalities in Patients with Chronic Kidney Disease in a Tertiary Hospital in Ivory Coast. Open Journal of Nephrology, 12, 3647.

https://doi.org/10.4236/ojneph.2022.121004

Received: January 3, 2022

Accepted: February 8, 2022

Published: February 11, 2022

Copyright $\odot 2022$ by author(s) and Scientific Research Publishing Inc. This work is licensed under the Creative Commons Attribution International License (CC BY 4.0).

http://creativecommons.org/licenses/by/4.0/

\begin{abstract}
Background: Cardiovascular risk factors (CVRF) are very frequent in patients with chronic kidney disease (CKD) and impose a new environment to which the heart must adapt. Cardiac ultrasound is a non-invasive and easyto-perform examination that allows quantitative and qualitative assessment of the anatomy and function of the heart. The objectives of this study were to describe abnormalities observed on trans-thoracic Doppler-echocar-diography and to investigate the factors associated with them. Materials and Method: This was a monocentric retrospective cross-sectional study conducted in CKD patients hospitalized in a hospital center in Côte d'Ivoire from January 2017 to December 2018. Results: One hundred and four cases were collected with a mean age of $48.87 \pm 14.47$ years and a sex ratio of 1.7. Patients with end-stage-renal-disease (ESRD) represented $83.7 \%$ with $55.8 \%$ of cases of chronic glomerulonephritis. Cardiovascular risk factors were $100 \%$ anemia, $84.6 \%$ inflammatory profile, $77.9 \%$ hypertension, $76.9 \%$ hypocalcemia and in $67.3 \%$ oedema. Cardiac abnormalities were observed in $78.8 \%$ of patients. Left ventricular hypertrophy (LVH), accounting for $20.2 \%$ of cases, was associated with male gender (OR $0.127 \mathrm{CI} 0.025-0.643 ; \mathrm{p}=0.013$ ) and hypertensive nephropathy (OR 0.189 CI $0.056-0.637 ; \mathrm{p}=0.007$ ). History of hypertension (OR 0.297 CI $0.084-1.050 ; \mathrm{p}=0.060$ ) and diabetes (OR $5.315 \mathrm{CI} 1.260$ 22.419; $\mathrm{p}=0.023$ ), hypertensive nephropathy (OR $0.174 \mathrm{CI} 0.052-0.585 ; \mathrm{p}=$ 0.005 ) and hypocalcemia (OR $6.094 \mathrm{CI} 1.723-21.559$; $\mathrm{p}=0.005)$ are incriminated in the development of left ventricular dilatation (LVD) which accounted for $38.5 \%$ of cases. Conclusion: Left ventricular hypertrophy and dilatation are the main echocardiographic abnormalities observed in our population.
\end{abstract}




\section{Keywords}

Chronic Renal Failure Left Ventricular Hypertrophy, Ivory Coast

\section{Introduction}

Chronic kidney disease remains a public health challenge because of its increasing frequency, its fatal cardiovascular consequences and its very costly management for public authorities. A subject suffering from CKD has a mortality risk multiplied by 20 to 30 compared to the general population of identical age [1]. One out of two deaths is related to the occurrence of cardiovascular complications [2]. The spectrum of cardiovascular diseases observed in CKD includes ischemic heart disease, congestive heart failure and cardiac arrhythmias. The prevalence of these complications is $69.8 \%$ and the risk of cardiovascular events increases exponentially with decreasing glomerular filtration rate (GFR) [3]. There are several ways to assess cardiovascular complications, including transthoracic cardiac ultrasound. It is a non-invasive examination with a reliable degree of accuracy, routinely used to explore the heart chambers. Left ventricular hypertrophy $(\mathrm{LVH})$, found in $60 \%-80 \%$ of patients with $\mathrm{CKD}$, is the most common morphological abnormality [4]. Dilated cardiomyopathy and calcifying valvulopathy may also be found [5]. Most of the patients in sub-Saharan Africa die because of lack of treatment for both CKD and the associated cardiovascular abnormalities [6]. There is paucity of local studies on cadiovascular abnormalities in patients with CKD in Cote d'Ivoire. Therefore, we initiated this work in order to evaluate the prevalence of echocardiographic abnormalities in patients with chronic renal failure not yet treated by hemodialysis and to identify the associated factors.

\section{Patients and Methods}

The study took place in the hospitalization unit of the Hemodialysis Nephrology Department of the University Teaching Hospital (CHU) of Yopougon in Abidjan in the Republic of Ivory Coast (RCI). It was a retrospective observational survey that was conducted over a period of two (2) years from January 1, 2017 to December 31, 2018. Were included patients aged more than 15 years, both sex, with established chronic kidney disease who have not received any form of renal replacement therapy, and who had a resting trans-thoracic echocardiography performed during their hospitalization. We excluded people less than 15 yars old or with acute kidney injury and patients with a history of cardiac disease followed by a cardiologist. From the hospitalization medical records, we collected on an individual survey form, socio-demographic parameters (age, sex, occupation, and educational level), clinical data (initial kidney disease, GFR, cardiovascular risk factors, and physical examination data), biological data (hemoglobin level, C-reactive protein (CRP), blood calcium, phosphorus, and creatinine 
levels), and echocardiographic data (functional abnormalities (hypokinesia, hyperkinesia), morphological abnormalities (hypertrophy, dilatation, pericardial detachment or effusion), and left ventricular systolic ejection fraction).

We adopted the following operational definitions:

- Glomerular filtration rate (GFR) was estimated using the simplified MDRD formula.

- CKD was characterized by a GFR $<60 \mathrm{ml} / \mathrm{mn} / 1.73 \mathrm{~m}^{2}$ persistent for more than three (3) months associated with normochromic normocytic anemia, hypocalcemia, hyperphosphatemia and small size kidneys $(<100 \mathrm{~mm})$.

- End-stage renal disease was defined as GFR $<15 \mathrm{ml} / \mathrm{min} / 1.73 \mathrm{~m}^{2}$.

- Chronic glomerulonephritis (CGN) associated a massive proteinuria $\geq 3$ $\mathrm{g} / 24 \mathrm{~h}$ and/or microscopic hematuria $>10,000 / \mathrm{ml}$ with blood cast, hypertension, edema and chronic renal failure.

- Hypertensive nephropathy was the combination of past history of hypertension, moderate proteinuria $1-2 \mathrm{~g} / 24 \mathrm{~h}, \mathrm{LVH}$ on electrocardiogram and on echocardiography, hypertensive retinopathy and CKD.

- Chronic tubulointerstitial nephropathy (CTIN) was defined by the absence of hypertension, edema and hematuria, the presence of leukocyturia $>10,000 / \mathrm{ml}$ without germs, and a history of urological disease.

- Fluid retention was characterized by the presence of limb edema, facial puffiness or ascites.

- HBP was defined as systolic blood pressure higher than or equal to $140 \mathrm{mmHg}$ and/or diastolic blood pressure higher than and/or equal to $90 \mathrm{mmHg}$ or regular use of antihypertensive drugs.

- Pericarditis was the presence of pericardial friction on physical examination, fluid effusion or pericardial detachment on cardiac ultrasound.

- Heart failure associated a hepato-jugular reflux, jugular turgor, painful hepatalgia or hepatomegaly, shortness of breath, gallop and tachycardia.

- Systolic dysfunction when the left ventricular ejection fraction was less than $50 \%$; it was said to be severe if less than $30 \%$.

- Left ventricular dilation was left ventricular telediastolic diameter indexed to body surface area $>31 \mathrm{~mm} / \mathrm{m}^{2}$ in men, $>32 \mathrm{~mm} / \mathrm{m}^{2}$ in women.

- Right atrial dilation characterized right atrial volume $\geq 35 \mathrm{ml} / \mathrm{m}^{2}$.

- Systolic dysfunction was left ventricular ejection fraction $\leq 50 \%$.

- Diastolic dysfunction was defined by a left ventricular ejection fraction $\leq$ $50 \%$ associated with mitral flow $\geq 2$ and an A-wave deceleration time $<150$ ms.

- Left ventricular hypertrophy (LVH) was reflected by left ventricular mass $\geq$ $110 \mathrm{~g} / \mathrm{m}^{2}$ in women and $\geq 135 \mathrm{~g} / \mathrm{m}^{2}$ in men.

- Hyperphosphoremia in case of phosphorus levels above $68 \mathrm{mg} / \mathrm{l}$.

- Hypocalcemia if blood calcium level $<88 \mathrm{mg} / \mathrm{l}$.

- Inflammatory profile when CRP was above $20 \mathrm{mg} / \mathrm{l}$.

- Anemia if the hemoglobin $(\mathrm{Hb})$ level was below $12 \mathrm{~g} / \mathrm{dl}$; anemia was said to 
be severe if the $\mathrm{Hb}$ level was below $6 \mathrm{~g} / \mathrm{dl}$.

Data analysis was performed using Stata16 software. First, we performed a descriptive analysis. Quantitative variables were described as average when their distribution was normal or otherwise as median. In bivariate analysis, the dependent variables were left ventricular dilatation and left ventricular hypertrophy, and the proportions of the qualitative variables were compared among patients with or without one of the above-mentioned echocardiographic abnormalities by a chi-square test or Fisher's exact test when the numbers were less than 5. For quantitative variables, averages and medians were compared by a STUDENT test, and relative quantitative variables were transformed into categorical variables according to pathological standards. The threshold of $\mathrm{p}<0.05$ was considered significant.

\section{Results}

From January 1, 2017 to December 31, 2018, the inpatient unit of the nephrology department of the University Hospital (CHU) of Yopougon registered 1269 patients (624 in 2017 and 645 in 2018). One hundred and four (104) patients (61 and 43 respectively in 2017 and 2018) were kept according to our inclusion criteria, i.e. $8.2 \%$ of hospitalized patients. Socio-demographic and clinical characteristics of patients are resumed in Table 1 . The mean age was 48 years $(\mathrm{SD}=$ 14.47) with extremes of 17 and 83 years. Etiologies of CKD were CGN in 55.8\% of cases, hypertensive nephropathy in $39.4 \%$ and CTIN in $4.8 \%$. The physical examination noted peripheral edema in 70 patients, associated with signs of cardiac (55 cases) and pulmonary (15 cases) congestion. Uncontrolled hypertension was present in 81 patients (77.9\%). All patients had clinical anemia. Serum creatinine ranged from 25 to $180 \mathrm{mg} / \mathrm{l}$ with a mean value of $82 \mathrm{mg} / \mathrm{l}$. According to estimated GFR, there were 7 cases of CKD grade $3 \mathrm{KDOQI}, 10$ cases of CKD grade 4 and 87 cases of CKD grade 5. 80 patients had an azotemia higher than 2 $\mathrm{g} / \mathrm{l}$. All patients had a biological anemia and the average hemoglobin level was 8 $\mathrm{g} / \mathrm{dl}$. Twenty four hour proteinuria more than $1 \mathrm{~g}$ was observed in 80 patients (76\%). Disturbances of the phosphocalcic balance (hypocalcemia and hyperphosphoremia) were presents in $77 \%$ of the patients. C-reactive protein was high in 82 patients. Table 2 shows the echocardiographic abnormalities observed in 82 patients, i.e. a frequency of $78.8 \%$ abnormality. Hypokinesia was the most common functional abnormality, i.e. $26 \%$ of cases, followed by hyperkinesia in $3.8 \%$ of cases. Morphological abnormalities observed on echocardiographic were dominated by chamber dilatation (62.5\%). Left ventricular dilatation (LVD) accounted for $38.5 \%$ of cases. Left ventricular hypertrophy (LVH) was found in $20.2 \%$ of cases. The average left ventricular ejection fraction was $57.24 \% \pm$ $13.47 \%$. We did not find any factors associated with the presence or absence of echocardiographic abnormalities in univariate analysis (Table 3 ). The proportion of male patients $(p=0.019)$ and subjects younger than 55 years $(p=0.02)$ was statistically higher in the group of those with LVH. Hypertensive nephropathy 
Table 1. Socio-demographic and clinical data of population studied.

\begin{tabular}{|c|c|c|}
\hline Data & $\mathrm{n}$ & $\%$ \\
\hline \multicolumn{3}{|l|}{ Gender } \\
\hline Female & 39 & 37.5 \\
\hline Male & 65 & 62.5 \\
\hline \multicolumn{3}{|l|}{ Age group } \\
\hline 17 - 35 years & 18 & 17.3 \\
\hline 36 - 55 years & 49 & 47.1 \\
\hline 56 - 75 years & 34 & 32.7 \\
\hline$\geq 76$ years & 3 & 2.9 \\
\hline \multicolumn{3}{|l|}{ Occupation } \\
\hline Workers & 21 & 20.2 \\
\hline Retired persons & 10 & 9.6 \\
\hline Unemployed & 63 & 60.6 \\
\hline Farmers & 10 & $9 ; 6$ \\
\hline \multicolumn{3}{|l|}{ Past medical history } \\
\hline HTA & 81 & 77.9 \\
\hline Diabetes & 21 & 20.6 \\
\hline Tobacco & 27 & 26 \\
\hline Alcohol & 41 & 39.4 \\
\hline \multicolumn{3}{|l|}{ Clinical signs } \\
\hline Fluids retention & 70 & 67.3 \\
\hline Hypertension & 62 & 57.6 \\
\hline Heart failure & 54 & 51.9 \\
\hline Acute pulmonary Edema & 16 & 15.4 \\
\hline
\end{tabular}

Table 2. Echocardiographic abnormalities in the 82 CKD patients.

\begin{tabular}{lccc}
\hline \multicolumn{2}{c}{ Echocardiographic abnormalities } & n & $\%$ \\
\hline Functional abnormalities & Hypokinesia & 27 & 26 \\
& Normokinesis & 73 & 70.2 \\
& Hyperkinesia & 4 & 3.8 \\
\hline Morphological abnormalities & & & \\
& Cavity dilatation & 65 & 62.5 \\
& Hypertrophy of walls & 35 & 33.6 \\
& Pericardial detachment & 23 & 22.1 \\
\hline Dilated chambers & & & \\
& Left atrium & 44 & 42.3 \\
& Left ventricle & 40 & 38.5 \\
& Right atrium & 10 & 9.6 \\
& Right ventricle & 10 & 9.6 \\
\hline
\end{tabular}




\section{Continued}

Enlarged walls

\begin{tabular}{|c|c|c|}
\hline Left atrium & 14 & 13.5 \\
\hline Left ventricle & 21 & 20.2 \\
\hline Right atrium & 02 & 1.92 \\
\hline Right ventricle & 01 & 0.92 \\
\hline Interventricular septum & 11 & 10.6 \\
\hline \multicolumn{3}{|l|}{ Left ventricular ejection fraction } \\
\hline$>70 \%$ & 15 & 12.5 \\
\hline $51 \%-70 \%$ & 71 & 58.7 \\
\hline $31 \%-50 \%$ & 30 & 25 \\
\hline$\leq 30 \%$ & 4 & 3.8 \\
\hline
\end{tabular}

Table 3. Factors associated with the presence or not of abnormalities observed on echocardiography in univariate analysis.

\begin{tabular}{|c|c|c|c|c|c|}
\hline \multicolumn{6}{|c|}{ Normal echocardiography } \\
\hline Parameters & No $(n=82)$ & Yes $(n=22)$ & p-value & OR & CI $(95 \%)$ \\
\hline \multicolumn{6}{|c|}{ Gender } \\
\hline Male & $53(64.6 \%)$ & $12(54.5 \%)$ & 0.38 & 1.52 & $0.59-3.96$ \\
\hline Female & $29(34.5 \%)$ & $10(45.5 \%)$ & 0.38 & 0.66 & $0.25-1.70$ \\
\hline \multicolumn{6}{|c|}{ Age range } \\
\hline$>55$ years old & $49(59.8 \%)$ & $15(68.2 \%)$ & 0.47 & 0.67 & $0.25-1.89$ \\
\hline$\leq 55$ years old & $33(40.2 \%)$ & $7(31.2 \%)$ & 0.47 & 1.44 & $0.53-3.92$ \\
\hline \multicolumn{6}{|c|}{ Medical history } \\
\hline $\mathrm{HBP}$ & $63(76.8 \%)$ & $18(81.8 \%)$ & 0.61 & 0.78 & $0.29-2.08$ \\
\hline Diabetes & $17(20.7 \%)$ & $4(18.2 \%)$ & 0.79 & 0.85 & $0.25-2.84$ \\
\hline \multicolumn{6}{|c|}{ Initial nephropathy } \\
\hline CGN & 45 (54.9\%) & $12(54.5 \%)$ & 0.72 & 0.84 & $0.32-2.19$ \\
\hline Hypertensive nephropathy & $33(40.2 \%)$ & $8(36.4 \%)$ & 0.74 & 1.18 & $0.45-3.12$ \\
\hline Interstitial nephropathy & $4(4.9 \%)$ & $2(9.1 \%)$ & 0.95 & 1.08 & $0.11-10.15$ \\
\hline \multicolumn{6}{|c|}{ CKD stage } \\
\hline $\mathrm{GFR}<15 \mathrm{ml} / \mathrm{min}$ & $68(82.9 \%)$ & $19(86.4 \%)$ & 0.69 & 0.76 & $0.19-2.95$ \\
\hline
\end{tabular}

$(\mathrm{p}=0.01), \operatorname{HSR}(\mathrm{p}=0.01), \mathrm{Hb}<8 \mathrm{~g} / \mathrm{dl}(\mathrm{p}=0.05)$ and CRP $\geq 20 \mathrm{mg} / \mathrm{dl}$ were associated with the occurrence of LVH LVD was related to female gender and age (Table 4). In multivariate analysis, male gender (OR 0.127 CI $0.025-0.643 ; \mathrm{p}=$ 0.013 ) and hypertensive nephropathy (OR 0.189 CI $0.056-0.637 ; \mathrm{p}=0.007$ ) were associated with the occurrence of LVH (Table 5). There was a statistical relationship between LVD and HBP $(\mathrm{p}=0.001)$, diabetes $(\mathrm{p}=0.004), \mathrm{CNG}(\mathrm{p}=$ $0.003)$, hypertensive nephropathy $(\mathrm{p}=0.059)$, GFR $<15 \mathrm{ml} / \mathrm{min}(\mathrm{p}=0.001)$, 
Table 4. Factors associated with the existence or not of left ventricular hypertrophy in univariate analysis.

\begin{tabular}{|c|c|c|c|c|c|}
\hline \multicolumn{6}{|c|}{ Left ventricular hypertrophy } \\
\hline Parameters & Yes $(n=21)$ & No $(n=14)$ & p-value & OR & CI (95\%) \\
\hline \multicolumn{6}{|c|}{ Gender } \\
\hline Male & $19(64.6 \%)$ & $7(50 \%)$ & 0.019 & 3.51 & $1.20-10.27$ \\
\hline Female & $2(9.5 \%)$ & $7(50 \%)$ & 0.33 & 0.43 & $0.08-2.42$ \\
\hline \multicolumn{6}{|c|}{ Age range } \\
\hline$<55$ years & $15(71.4 \%)$ & $6(42.9 \%)$ & 0.02 & 3.47 & $1.13-10.68$ \\
\hline$\geq 55$ years & $6(28.6 \%)$ & $8(57.1 \%)$ & 0.97 & 1.02 & $0.27-3.80$ \\
\hline \multicolumn{6}{|c|}{ Medical history } \\
\hline HBP & $17(80.9 \%)$ & $13(92.8 \%)$ & 0.18 & 1.87 & $0.75-4.65$ \\
\hline Diabetes & $2(9.5 \%)$ & $5(35.7 \%)$ & 1.22 & 0.22 & $0.03-1.59$ \\
\hline \multicolumn{6}{|c|}{ Initial nephropathy } \\
\hline CGN & $8(38.1 \%)$ & $9(64.3 \%)$ & 0.96 & 1.03 & $0.33-3.20$ \\
\hline Hypertensive nephropathy & $13(61.9 \%)$ & $3(21.4 \%)$ & 0.01 & 1.18 & $0.45-3.12$ \\
\hline CTIN & 0 & $2(14.3 \%)$ & - & - & - \\
\hline \multicolumn{6}{|c|}{ CKD stage } \\
\hline $\mathrm{GFR}<15 \mathrm{ml} / \mathrm{min}$ & $18(85.7 \%)$ & $12(85.7 \%)$ & 0.15 & 1.92 & $0.78-4.71$ \\
\hline $\mathrm{GFR} \geq 15 \mathrm{ml} / \mathrm{min}$ & $3(14.3 \%)$ & $2(14.3 \%)$ & 0.31 & 3.00 & $0.35-25.87$ \\
\hline \multicolumn{6}{|c|}{ Clinical signs } \\
\hline RHS & $4(19.05 \%)$ & $7(50 \%)$ & 0.01 & 3.45 & $1.20-9.94$ \\
\hline $\mathrm{TAS} \geq 160 \mathrm{mmHg}$ & $8(38.1 \%)$ & $11(78.6 \%)$ & 0.30 & 1.77 & $0.60-5.25$ \\
\hline $\mathrm{TAD} \geq 100 \mathrm{mmHg}$ & $9(42.9 \%)$ & $7(50 \%)$ & 0.24 & 2.14 & $0.59-7.77$ \\
\hline \multicolumn{6}{|c|}{ Biological signs } \\
\hline Hb level $<8 \mathrm{~g} / \mathrm{dl}$ & $15(71.4 \%)$ & $7(50 \%)$ & 0.05 & 2.86 & $0.96-8.46$ \\
\hline Hypocalcemia & $14(66.7 \%)$ & $13(92.8 \%)$ & 0.92 & 0.99 & $0.39-2.53$ \\
\hline Hyperphosphatemia & $11(52.4 \%)$ & $7(50 \%)$ & 0.39 & 1.68 & $0.51-5.56$ \\
\hline $\mathrm{CRP} \geq 20 \mathrm{mg} / \mathrm{l}$ & $19(90.5 \%)$ & $12(85.7 \%)$ & 0.03 & 2.71 & $1.1-6.68$ \\
\hline
\end{tabular}

Table 5. Factors associated with the occurrence of left ventricular hypertrophy in multivariate analysis.

\begin{tabular}{ccccc}
\hline & \multicolumn{3}{c}{ Confidence interval } \\
\hline Variables & p-value & GOLD & Lower & Superior \\
\hline & \multicolumn{2}{c}{ Socio-demographic data } & & \\
Age $<55$ years & 0.39 & 1.691 & 0.500 & 5.719 \\
Male & $\mathbf{0 . 0 1 3}$ & 0.127 & 0.025 & 0.643 \\
\hline & Initial nephropathy & & \\
Hypertensive nephropathy & $\mathbf{0 . 0 0 7}$ & 0.189 & 0.056 & 0.637 \\
\hline & Clinico-biological data & & \\
Fluids retention & 0.104 & 3.178 & 0.789 & 12.795 \\
Hb $<8 / \mathrm{dl}$ & 0.136 & 0.386 & 0.110 & 1.349 \\
CRP $>20$ mg $/ 1$ & 0.932 & 1.081 & 0.180 & 6.504 \\
\hline
\end{tabular}


SHR ( $=0.029)$, SBP $\geq 160 \mathrm{mmHg}(\mathrm{p}=0.010), \mathrm{Hb}<8 \mathrm{~g} / \mathrm{dl}(\mathrm{p}=0.012)$, hypocalcemia ( $<0.001)$, and CRP $\geq 20 \mathrm{mg} / \mathrm{l}(\mathrm{p}=0.006$ ) (Table 6). In multivariate analysis, history of hypertension $(\mathrm{p}=0.060)$ and diabetes $(\mathrm{p}=0.023)$, hypertensive nephropathy $(\mathrm{p}=0.005)$ and hypocalcemia $(\mathrm{p}=0.005)$ were associated with the occurrence of LVD (Table 7).

\section{Discussion}

Declining GFR is accompanied by an exponential increase in cardiovascular risk. We conducted this study to evaluate echocardiographic abnormalities in a population of chronic renal failure patients from black Africa. In our study, the age group 36 - 54 years represented $47.1 \%$ of the population and the average age was

Table 6. Relationship between clinico-biological data and the occurrence of left ventricular dilatation in univariate analysis.

\begin{tabular}{|c|c|c|c|c|c|}
\hline \multicolumn{6}{|c|}{ Left ventricular dilatation } \\
\hline Parameters & Yes $(n=40)$ & No $(n=25)$ & p-value & OR & CI (95\%) \\
\hline \multicolumn{6}{|c|}{ Gender } \\
\hline Male & $27(67.5 \%)$ & $15(60 \%)$ & 0.051 & 2.80 & $0.98-7.99$ \\
\hline Female & $13(32.5 \%)$ & $10(40 \%)$ & 0.001 & 19.5 & $2.19-173.5$ \\
\hline \multicolumn{6}{|c|}{ Age range } \\
\hline$<55$ years & $25(62.5 \%)$ & $13(52 \%)$ & 0.006 & 4.33 & $1.49-12.6$ \\
\hline$\geq 55$ years & $15(37.5 \%)$ & $12(48 \%)$ & 0.016 & 6.87 & $1.27-37.15$ \\
\hline \multicolumn{6}{|c|}{ Medical history } \\
\hline HBP & $10(25 \%)$ & $7(28 \%)$ & 0.001 & 5.21 & $1.94-13.99$ \\
\hline Diabetes & $10(25 \%)$ & $3(12 \%)$ & 0.004 & 23.33 & $1.99-273.3$ \\
\hline \multicolumn{6}{|c|}{ Initial nephropathy } \\
\hline CGN & $21(52.5 \%)$ & $12(48 \%)$ & 0.003 & 5.54 & $1.74-17.7$ \\
\hline Hypertensive nephropathy & $19(47.5 \%)$ & $10(40 \%)$ & 0.059 & 3.8 & $0.91-15.78$ \\
\hline CTIN & $0(0 \%)$ & $3(12 \%)$ & - & - & - \\
\hline \multicolumn{6}{|c|}{ CKD stage } \\
\hline $\mathrm{GFR}<15 \mathrm{ml} / \mathrm{min}$ & $33(82.5 \%)$ & $19(76 \%)$ & 0.001 & 4.34 & $1.72-10.96$ \\
\hline \multicolumn{6}{|c|}{ Clinical signs } \\
\hline Fluid retention & $28(70 \%)$ & $18(72 \%)$ & 0.029 & 3.11 & $1.10-8.75$ \\
\hline $\mathrm{TAS} \geq 160 \mathrm{mmHg}$ & $19(47.5 \%)$ & $12(48 \%)$ & 0.010 & 4.49 & $1.38-14.57$ \\
\hline $\mathrm{TAD} \geq 100 \mathrm{mmHg}$ & $12(30 \%)$ & $10(40 \%)$ & 0.180 & 2.14 & $0.59-7.77$ \\
\hline \multicolumn{6}{|c|}{ Biological signs } \\
\hline Hb level < $8 \mathrm{~g} / \mathrm{dl}$ & $25(62.5 \%)$ & $14(56 \%)$ & 0.012 & 3.79 & $1.31-11.01$ \\
\hline Hypocalcemia & $35(87.5 \%)$ & $16(64 \%)$ & 0.000 & 8.02 & $2.73-23.6$ \\
\hline Hyperphosphatemia & $18(45 \%)$ & $14(56 \%)$ & 0.539 & 1.47 & $0.43-5.03$ \\
\hline $\mathrm{CRP} \geq 20 \mathrm{mg} / \mathrm{l}$ & $32(80 \%)$ & $25(100 \%)$ & 0.006 & 3.6 & $1.41-9.61$ \\
\hline
\end{tabular}


Table 7. Factors associated with the occurrence of left ventricular dilatation in multivariate analysis.

\begin{tabular}{|c|c|c|c|c|}
\hline \multirow[b]{2}{*}{ Variables } & \multirow[b]{2}{*}{ p-value } & \multirow[b]{2}{*}{ OR } & \multicolumn{2}{|c|}{ Confidence interval } \\
\hline & & & Inferior & Superior \\
\hline \multicolumn{5}{|c|}{ Socio-demographic data } \\
\hline Age $<55$ years & 0.196 & 2.152 & 0.673 & 6.877 \\
\hline Male & 0.199 & 0.521 & 0.193 & 1.409 \\
\hline \multicolumn{5}{|c|}{ Medical history } \\
\hline HBP & 0.060 & 0.297 & 0.084 & 1.050 \\
\hline Diabetes & 0.023 & 5.315 & 1.260 & 22.419 \\
\hline \multicolumn{5}{|c|}{ Initial nephropathy } \\
\hline Hypertensive nephropathy & 0.005 & 0.174 & 0.052 & 0.585 \\
\hline \multicolumn{5}{|c|}{ Clinico-biological data } \\
\hline Fluids retention & 0.930 & 1.047 & 0.378 & 2.898 \\
\hline $\mathrm{GFR}<15 \mathrm{ml} / \mathrm{min}$ & 0.631 & 1.392 & 0.361 & 5.369 \\
\hline $\mathrm{SAR}>160 \mathrm{mmHg}$ & 0.289 & 0.599 & 0.233 & 1.543 \\
\hline $\mathrm{Hb}$ level $<8 \mathrm{~g} / \mathrm{dl}$ & 0.506 & 0.702 & 0.247 & 1.991 \\
\hline Hypocalcemia & 0.005 & 6.094 & 1.723 & 21.559 \\
\hline $\mathrm{CRP}>20 \mathrm{mg} / \mathrm{l}$ & 0.131 & 0.397 & 0.120 & 1.318 \\
\hline
\end{tabular}

$48.87 \pm 14.47$ years. There were $62.5 \%$ male patients with a sex ratio of $1.7 \mathrm{in} \mathrm{fa-}$ vor of men. These proportions are comparable to those found in the different studies conducted in Ghana and Nepal [7] [8]. The mean age was $43.9 \pm 17.8$ years and $59.36 \pm 14.337$ years respectively in Nepal and in Ghana [7] [8]. The predominance of male gender was also reported by Yaw et al. as 64.5\% [8]. The predominance of chronic renal failure in relatively young males can be explained in part by the role of environmental factors, notably smoking, alcoholism and occupational exposure, in the occurrence and progression of renal pathologies [9]. The frequency of chronic end-stage renal disease (GFR $<15 \mathrm{ml} / \mathrm{mn} / 1.73 \mathrm{~m}^{2}$ ) in our series was $83.7 \%$. It was reported $51.2 \%$ in Uganda [10]. The causes of chronic renal failure were dominated by chronic glomerulonephritis (55.8\%) and hypertensive nephropathy (39.1\%) In Nepal, hypertensive (35\%) and diabetic (31\%) nephropathy were the main causes of chronic failure followed by chronic glomerulonephritis (14\%) [7]. CKD due to the progression of hypertensive disease, is more frequent in black subjects than in Caucasians. There is a genetic predisposition of the black race to develop CKD more rapidly. The association of HBP and CKD is very frequent and most chronic kidney diseases are complicated by hypertension at the terminal stage [11]. In addition to the socalled classical risk factors (sedentary lifestyle, dyslipidemia, arterial hypertension, diabetes, chronic alcoholism, chronic smoking and obesity) that patients with CKD share with the general population, they have risk factors that are spe- 
cific to them such as anemia, chronic inflammatory profile, fluids retention, arteriovenous fistula and phosphocalcic disorders [12]. In our series, we reported arterial hypertension (77.9\%), smoking (26\%), diabetes (20.2\%) and drug abuse (1\%). Indeed, all kidney diseases can be complicated by hypertension at the terminal stage, probably due to chronic stimulation of the renin-angiotensinaldosterone system [10]. During CKD, the left ventricle undergoes structural and functional changes secondary to pressure and volume overload and cell apoptosis [13]. Out of 104 chronic renal failure patients who performed transthoracic echocardiography, 82 patients $(78.8 \%)$ had an abnormality. Our data is comparable to those of some authors which reported $74 \%$ of abnormalities [7]. Regarding the functional data, in our series we reported $26 \%$ of hypokinesia and $3.8 \%$ of hyperkinesia. The preponderance of hypokinesia was found in the study by Fongoro in Mali with $44.74 \%$ of cases [14]. Structurally, the morphological abnormalities observed on cardiac ultrasound were dominated by chamber dilatation (62.5\%), wall hypertrophy (33.6\%) and pericardial detachment (22.1\%). In Africa, several studies showed higher frequencies of pericarditis on echocardiography. Thus in Uganda and Mali the frequency was respectively $22 \%$ and $19.04 \%$ [10] [14]. In our study, the changes (dilatation and hypertrophy) of the cardiac structure concerned preferentially the left heart (left ventricle and left atrium). These changes appear to be adaptive responses to pressure and volume overload by stretching existing myocytes and thus increasing the internal dimensions of the left ventricle [15]. Out of the 35 cases of cardiac wall hypertrophy (33.6\%), 21 cases of left ventricular hypertrophy (20.2\%) were collected. Studies carried out in Uganda, Ghana and Nepal reported cases of left ventricular hypertrophy with proportions of $54.4 \%, 43 \%$, and $49 \%$ respectively [7] [8] [9]. In literature, the prevalence of left ventricular hypertrophy (LVH) in the population of CKD would vary between $60 \%$ - 75\% [16] [17]. Regarding the associated factors, only male gender and hypertensive nephropathy were associated with the occurrence of LVH in our study. In the study by Yaw in Ghana, in addition to male gender, the occurrence of cardiac abnormality such as left ventricular hypertrophy was caused by systolic blood pressure (SBP), diastolic blood pressure (DBP) and body mass index (BMI) [8]. Out of the 65 cases of heart chamber dilatation (62.5\%), 40 concerned the left ventricle (38.5\%). Our result was similar to that found in Mali by Fongoro who reported $40.47 \%$ of cases of dilatation of the left ventricle [14]. Dilatation permits to increase cardiac output at a comparable level of energy spending, whereas wall thickening redistributes the increased wall tension over a wider area [4]. A history of hypertension and diabetes, hypertensive nephropathy, and hypocalcemia are incriminated in the development of left ventricular dilatation. The analysis of left ventricular systolic function by cardiac ultrasound is done by measuring the percentage of shortening and the left ventricular ejection fraction [18]. The average left ventricular ejection fraction was $57.24 \% \pm 13.47 \%$ with extremes of 20 and $87 \%$. Thirty patients, which is $28.8 \%$ had an ejection fraction of less than $50 \%$. In 
Uganda, the left ventricular ejection fraction was lower than $50 \%$ in $18.9 \%$ of patients [10]. This dysfunction is multifactorial including coronary insufficiency, anemia, hyperparathyroidism, uremic toxins, malnutrition and prolonged hemodynamic overload [15].

\section{Conclusion}

Our study demonstrates the high frequency of LVH and LVD on trans-thoracic echocardiography of advanced chronic renal failure in an Ivorian hospital. Left ventricular hypertrophy (LVH) was associated with male gender and hypertensive nephropathy. History of hypertension and diabetes, hypertensive nephropathy and hypocalcemia were incriminated in the development of LVH. These left ventricular abnormalities were thus associated with traditional cardiovascular risk factors and severe renal impairment. Echocardiographic evaluation studies should be performed in the early stage of chronic kidney disease for early detection of cardiac abnormalities.

\section{Conflicts of Interest}

The authors declare no conflicts of interest regarding the publication of this paper.

\section{References}

[1] Foley, R.N. and Collins, A.J. (2007) End-Stage Renal Disease in the United States: An Update from the United States Renal Data System. Journal of the American Society of Nephrology, 18, 2644-2648. https://doi.org/10.1681/ASN.2007020220

[2] Manjunath, G., Tighiouart, H., Coresh, J., et al. (2003) Level of Kidney Function as a Risk Factor for Cardiovascular Outcomes in the Elderly. Kidney International, 63, 1121-1129. https://doi.org/10.1046/j.1523-1755.2003.00838.x

[3] Lullo, L.D., Gorini, A., Russo, D., Santoboni, A. and Ronco, C. (2015) Left Ventricular Hypertrophy in Chronic Kidney Disease Patients: From Pathophysiology to Treatment. Cardiorenal Medicine, 5, 254-266. https://doi.org/10.1159/000435838

[4] Wheeler, D.C. (2002) Cardiomyopathie urémique. Flammarion Médecine-Sciences, Actualités Néphrologiques.

[5] Herzog, C.A., Asinger, R.W., Berger, A.K., et al. (2011) Cardiovascular Disease in Chronic Kidney Disease. A Clinical Update from Kidney Disease: Improving Global Outcomes (KDIGO). Kidney International, 80, 572-586. https://doi.org/10.1038/ki.2011.223

[6] Sumaili, E.K., Krzesinski, J.M., Zinga, C.V., Cohen, E.P., Delanaye, P., et al. (2009) Prevalence of Chronic Kidney Disease in Kinshasa: Results of a Pilot Study from the Democratic Republic of Congo. Nephrology Dialysis Transplantation, 24, 117-122. https://doi.org/10.1093/ndt/gfn469

[7] Panjiyar, R., Sharma, R., Laudari, S., Gutpa, M., Ghimire, M., Subedi, P. and Ubramanyam, G. (2017) Cardiovascular Complications in End Stage Renal Disease in a Tertiary Hospital in Nepal. Journal of College of Medical Sciences-Nepal, 13, 279 283.

[8] Yaw, A.A., Laryea, D.O., Bedu-Addo, G., Nkum, B.C. and Plange-Rhule, J. (2017) Left Ventricular Hypertrophy among Chronic Kidney Disease Patients in Ghana. 
The Pan African Medical Journal, 28, 79-88.

[9] Keates, A.K., Mocumbi, A.O., Ntsekhe, M., Sliwa, K. and Stewart, S. (2017) Cardiovascular Disease in Africa: Epidemiological Profile and Challenges. Nature Reviews Cardiology, 14, 273-293.

[10] Babua, C., Kalyesubula, R., Okello, E., Kakande, B., Sebatta, E., Mungoma, M. and Mondo, C. (2015) Pattern and Presentation of Cardiac Diseases among Patients with Chronic Kidney Disease Attending a National Referral Hospital in Uganda: A Cross Sectional Study. BMC Nephrology, 16, Article No. 126.

https://doi.org/10.1186/s12882-015-0128-Z

[11] Mailloux, L.U. and Levey, A.S. (1998) Hypertension in Patients with Chronic Renal Disease. American Journal of Kidney Diseases, 32, S120-S141.

https://doi.org/10.1053/ajkd.1998.v32.pm9820471

[12] Zoccali, C., Mallamaci, F. and Tripepi, G. (2003) Traditional and Emerging Cardiovascular Risk Factors in End-Stage Renal Disease. Kidney International, 85, S105S110. https://doi.org/10.1046/j.1523-1755.63.s85.25.x

[13] Muntner, P., He, J., Astor, B.C., Folsom, A.R. and Coresh, J. (2005) Traditional and Non-Traditional Risk Factors Predict Coronary Heart Disease in Chronic Kidney Disease: Results from the Atherosclerosis Risk in Communities Study. Journal of the American Society of Nephrology, 16, 529-538. https://doi.org/10.1681/ASN.2004080656

[14] Lahlou, I., Ouaha, L., El Ouali, L. and Akoudad, H. (2010) Echo-Doppler cardiaque chez l'hémodialysé chronique. Journal Marocain de Cardiologie, 2, 13-20.

[15] Fongoro, S., Maïga, M.K., Ben, A. and Diarra, I. (2003) les complications cardiaques chez l'insuffisant rénal chronique dans le service de néphrologie et d'hémodialyse de l'hôpital national du point g. Mali Médical, 18, 12-16.

[16] Parfray, P.S. and Foley, R.N. (1999) The Clinical Epidemiology of Cardiac Disease in Chronic Renal Failure. Journal of the American Society of Nephrology, 10, 16061615. https://doi.org/10.1681/ASN.V1071606

[17] Schiffrin, E., Lipman, M.L. and Mann, F.E. (2007) Chronic Kidney Disease: Effects on the Cardiovascular System. Circulation, 116, 85-97. https://doi.org/10.1161/CIRCULATIONAHA.106.678342

[18] Wang, T.J., Evans, J.C., Benjamin, E.J., Levy, D., Leroy, E.C. and Vasan, R.S. (2003) Natural History of Asymptomatic Left Ventricular Systolic Dysfunction in the Community. Circulation, 108, 977-982. https://doi.org/10.1161/01.CIR.0000085166.44904.79 